\title{
Gambaran Klinis dan Histolopatologis Pasien Karsinoma Kavum Nasal dan Sinus Paranasal di Bagian THT-KL RSUP Dr. M. Djamil Padang Tahun 2016 - 2018
}

\author{
Melita Husna ${ }^{1}$, Sukri Rahman², Erlina Rustam³
}

\begin{abstract}
Abstrak
Karsinoma kavum nasal dan sinus paranasal merupakan keganasan yang jarang terjadi namun bersifat agresif. Kelangkaan kasus keganasan ini menyebabkan sebagian besar pasien datang pada stadium lanjut. Tujuan penelitian ini adalah menentukan gambaran klinis dan histopatologis karsinoma kavum nasal dan sinus paranasal di Bagian THT-KL RSUP Dr. M. Djamil Padang. Penelitian ini merupakan penelitian deskriptif retrospektif menggunakan data rekam medis dengan teknik total sampling. Sampel penelitian sebanyak 51 pasien yang didiagnosis karsinoma kavum nasal dan sinus paranasal di Bagian THT-KL RSUP Dr. M. Djamil Padang tahun 2016 - 2018. Hasil penelitian menunjukkan sebagian besar pasien adalah pria (60,78\%), kelompok usia 41 - 50 tahun (35,29\%), dan bekerja sebagai petani $(37,25 \%)$. Keluhan utama dan gejala klinis terbanyak adalah hidung tersumbat yaitu sebanyak $(45,09 \%)$ dan (86,27\%). Lokasi tersering ditemukan pada kavum nasal $(62,74 \%)$. Pasien datang pada stadium III dan IV, dengan tipe histopatologi terbanyak adalah squamous cell carcinoma (58,82\%). Kesimpulan penelitian ini bahwa pasien paling banyak ditemukan jenis kelamin laki-laki dengan keluhan utama dan gejala klinis terbanyak yang dialami adalah hidung tersumbat berlokasi di kavum nasal datang pada stadium III dan IV dengan tipe histopatologi squamous cell carcinoma.
\end{abstract}

Kata kunci: karsinoma, kavum nasal, sinus paranasal

\begin{abstract}
Nasal cavity carcinoma and paranasal sinuses are rare but aggressive malignancies. This scarcity of cases of malignancy causes most patients to come at an advanced stage. The objecive of this study was to determine the clinical and histopathological description of nasal cavity carcinoma and paranasal sinuses in the ENT-KL section of Dr. RSUP M. Djamil Padang. This research is a retrospective descriptive study using medical record data with a total sampling technique. The study sample was 51 patients diagnosed with nasal cavity carcinoma and paranasal sinuses in the ENT-KL section of Dr. RSUP M. Djamil Padang in 2016 - 2018. The results showed that the majority of patients were male $(60.78 \%)$, the age group $41-50$ years $(35.29 \%)$, and worked as farmers $(37.25 \%)$. The main complaints and most clinical symptoms were nasal congestion (45.09\%) and (86.27\%). The most common location is found in the nasal cavity (62.74\%). Patients came in stages III and IV, with the most histopathological type being squamous cell carcinoma (58.82\%). This study concludes that most patients found male sex with major complaints and the most clinical symptoms experienced were nasal congestion located in the nasal cavity coming in stage III and IV with histopathological type squamous cell carcinoma.
\end{abstract}

Keywords: carcinoma, nasal cavity, paranasal sinuses

Affiliasi penulis: 1. Prodi Pendidikan Dokter Fakultas Kedokteran Universitas Andalas Padang (FK UNAND), 2. Bagian THT-KL FK UNAND/RSUP Dr. M. Djamil Padang, 3. Bagian Patologi Anatomi FK UNAND/RSUP Dr. M. Djamil Padang
Korespondensi: Sukri Rahman, email: sukri_rahman@yahoo.com Telp: 081266404069 


\section{PENDAHULUAN}

Karsinoma kavum nasal dan sinus paranasal merupakan keganasan yang jarang terjadi namun bersifat agresif. ${ }^{1}$ Secara global, prevalensi kasus ini yaitu $5 \%$ dari keganasan pada kepala dan leher, dan kurang dari $1 \%$ dari seluruh keganasan. ${ }^{2}$ Prevalensi keganasan ini berkisar 1 banding 100.000 penduduk per tahun. ${ }^{1}$ Berdasarkan data American Cancer Society tahun 2018, kejadian keganasan kavum nasal dan sinus paranasal sebanyak 2000 penduduk per tahun. ${ }^{3}$ Negara Asia dilaporkan memiliki prevalensi tertinggi, terutama di Jepang yaitu 2 per 10.000 penduduk per tahun. ${ }^{4}$ Beberapa penelitian mengenai keganasan kavum nasal dan sinus paranasal telah dilakukan di Indonesia. Penelitian yang dilakukan di RSUP H. Adam Malik Medan melaporkan terdapat 112 pasien karsinoma kavum nasal dan sinus paranasal selama 2010 - 2015 dengan prevalensi tertinggi pada tahun 2014 yaitu sejumlah 39 pasien. ${ }^{5}$ Pada penelitian yang dilakukan oleh Rahman (2016), terdapat 15 pasien yang didiagnosis dengan keganasan kavum nasal dan sinus paranasal di bagian THT-KL RSUP Dr.M.Djamil Padang selama $2010-2013{ }^{6}$

Kasus keganasan kavum nasal dan sinus paranasal secara global terdapat pada rentang usia antara 50 sampai 60 tahun. ${ }^{1}$ Menurut American Cancer Society tahun 2018, keganasan ini sering terdapat pada usia lebih dari 55 tahun. $^{3}$ Penelitian yang dilakukan di bagian Poliklinik THT-KL RSUP Dr.Hasan Sadikin Bandung mendapatkan bahwa keganasan ini ditemukan pada usia di atas 51 tahun. ${ }^{7}$ Penelitian yang dilakukan di bagian THT-KL RSUP Dr.M.Djamil Padang didapatkan usia pasien yaitu pada median 44 tahun. $^{8}$

Kejadian karsinoma kavum nasal dan sinus paranasal lebih banyak ditemukan pada laki-laki dibandingkan dengan perempuan. ${ }^{9}$ Menurut penelitian Haque et al, terdapat 29 pasien laki-laki (72,5\%) dan 11 pasien perempuan $(27,5 \%)$ dimana perbandingan laki-laki dengan perempuan yaitu 2,6:1. ${ }^{10}$ Pada penelitian Turner dan Reh (2012), kejadian karsinoma kavum nasal dan sinus paranasal berdasarkan jenis kelamin memiliki perbandingan 1,8:1 pada laki-laki dan perempuan. ${ }^{11}$

Penyebab keganasan ini belum diketahui secara pasti namun pekerjaan merupakan salah satu faktor yang mempengaruhi keganasan ini. Seperti pada pekerja yang terpapar langsung oleh debu kayu dan pekerja industri kulit akan tetapi hal tersebut tergantung dari jumlah zat dan waktu paparan seseorang selama bekerja. Risiko keganasan ini meningkat pada seseorang yang terpapar formaldehid, bekerja di industri tekstil, konstruksi, serta senyawa nikel dan krom. Hubungan jenis histopatologis dan lokasi anatomis dengan paparan akibat kerja belum terbukti dengan jelas karena masih sedikit penelitian yang menentukan secara pasti perjalanan keganasan tersebut. $^{12}$

Keluhan utama dan gejala klinis keganasan kavum nasal dan sinus paranasal yang sering ditemukan yaitu hidung tersumbat, terdapat sekret pada hidung, keluar darah dari hidung, nyeri pada wajah. ${ }^{1}$ Keluar darah dari hidung merupakan keluhan utama pasien (93,3\%) dan disusul oleh hidung tersumbat $(80 \%) .^{13}$

Penelitian Mahalingappa dan Khalil pada tahun 2014 melaporkan bahwa kavum nasal menjadi lokasi utama pada keganasan ini yaitu 43,9\% disusul sinus maksila $(35,9 \%)$ dan sinus lainnya. ${ }^{14}$ Lokasi tersebut dekat dengan mata, dasar tengkorak, dan sistem saraf pusat, sehingga sulit untuk ditatalaksana. ${ }^{4}$

Diagnosis pasti dapat ditegakkan melalui biopsi dengan pendekatan endoskopi melalui hidung dan pemeriksaan histopatologi. ${ }^{8} \quad$ Klasifikasi histopatologi yang digunakan saat ini adalah WHO. ${ }^{15}$ Terdapat perbedaan distribusi tipe histologi di setiap negara. Secara umum, bentuk mikroskopis karsinoma kavum nasal dan sinus paranasal terbagi menjadi squamous cell carcinoma, verrucous carcinoma, lymphoepithelial carcinoma, sinonasal undifferentiated carcinoma, adeno-carcinoma, salivary gland-type carcinomas, dan neuroendocrine tumours. Bentuk yang sering ditemukan pada keganasan ini yaitu squamous cell carcinoma (50\%), adenocarcinoma (22\%), dan bentuk lainnya (28\%).

Stadium keganasan ditentukan berdasarkan riwayat pasien, pemeriksaan fisik, rontgen thorax, serta computed tomography (CT) dan/atau magnetic resonance imaging (MRI). ${ }^{16}$ Tatalaksana yang paling sering dilakukan adalah pembedahan disertai dengan radioterapi pasca operasi, idealnya dilakukan dalam enam minggu dan perlu perencanaan yang baik serta 
membutuhkan multidisiplin tinggi bersama bidang lain yang bersangkutan. Selain itu, kemoterapi juga menjadi pilihan tatalaksana pada keganasan ini. Dilaporkan bahwa pasien yang menjalani reseksi endonasal mendapatkan hasil lebih baik yang ditunjukkan dengan rendahnya morbiditas dan masa rawat inap yang lebih pendek. ${ }^{15}$ Umumnya pasien tersebut memiliki harapan hidup hingga 5 tahun. ${ }^{4}$

Kelangkaan kasus keganasan kavum nasal dan sinus paranasal menyebabkan sebagian besar pasien datang pada stadium lanjut karena tidak mengetahui gejala keganasan ini. Pengetahuan pasien dan petugas tentang gejala keganasan ini akan membantu untuk deteksi lebih awal. Oleh karena itu, peneliti merasa perlu mengetahui gambaran klinis dan histopatologis karsinoma kavum nasal dan sinus paranasal di bagian THT-KL RSUP Dr. M. Djamil Padang.

\section{METODE}

Penelitian ini adalah penelitian deskriptif retrospektif dengan menggunakan data sekunder dari rekam medis. Jenis penelitian ini adalah studi observasional dengan desain cross sectional. Penelitian ini dilaksanakan di bagian rekam medis dan bagian THT-KL RSUP Dr. M. Djamil Padang. Penelitian dilaksanakan pada Desember 2018 - Maret 2019.

Populasi penelitian yang diambil adalah pasien yang terdaftar ke Bagian THT-KL RSUP Dr. M. Djamil Padang yang didiagnosis karsinoma kavum nasal dan sinus paranasal oleh dokter spesialis THTKL selama periode Januari 2016 - Desember 2018.

Sampel penelitian adalah seluruh pasien karsinoma kavum nasal dan sinus paranasal yang terdaftar di Bagian THT-KL RSUP Dr. M. Djamil Padang periode Januari 2016 - Desember 2018 yang tercatat pada rekam medis dan memenuhi kriteria inklusi dan tidak memiliki kriteria eksklusi. Kriteria Inklusi: pasien dengan diagnosis karsinoma kavum nasal dan sinus paranasal oleh dokter spesialis THT$\mathrm{KL}$, pasien yang memiliki kelengkapan data (identitas, keluhan utama, gejala klinis, stadium tumor, lokasi tumor, hasil pemeriksaan patologi anatomi yang terdapat tipe histopatologi). Kriteria Eksklusi: data pada rekam medis yang dibutuhkan untuk penelitian tidak lengkap atau hilang.

Besar sampel minimal dihitung dengan menggunakan rumus untuk penelitian deskriptif kategorik, didapatkan sampel minimal yang dibutuhkan untuk penelitian ini sebesar 41 orang. Teknik sampling yang digunakan dalam penelitian ini adalah total sampling pada pasien yang memenuhi kriteria inklusi dan eksklusi. Alur penelitian dimulai dengan mengambil data nomor rekam medis pasien karsinoma kavum nasal dan sinus paranasal di bagian THT-KL dan rekam medis di bagian rekam medis RSUP Dr. M. Djamil Padang. Data-data yang diperlukan yaitu nomor rekam medis, jumlah pasien karsinoma kavum nasal dan sinus paranasal, jenis kelamin pasien, usia pasien, pekerjaan, keluhan utama, gejala klinis, lokasi tumor, stadium tumor, dan tipe histopatologi. Pada masingmasing data pasien dilakukan pemilihan subjek yang memenuhi kriteria inklusi dan eksklusi sampel dilanjutkan dengan mengolah dan menganalasis data.

\section{HASIL}

\section{Distribusi Penderita Karsinoma Kavum Nasal dan Sinus Paranasal Berdasarkan Tahun}

Pasien yang didiagnosis karsinoma kavum nasal dan sinus paranasal yang berobat di Bagian THT-KL RSUP Dr. M. Djamil Padang tahun 2016-2018 terdapat sebanyak 51 orang, dengan jumlah pasien yang datang setiap tahun dapat dilihat pada tabel 4.1, dimana kejadian tertinggi pada tahun 2016 dengan jumlah pasien 20 orang (39,21\%).

Tabel 1. Distribusi penderita karsinoma kavum nasal dan sinus paranasal berdasarkan tahun kejadian

\begin{tabular}{lcc}
\hline Tahun & $\boldsymbol{f}(\mathbf{n}=\mathbf{5 1})$ & $\%$ \\
\hline 2016 & 20 & 39,21 \\
2017 & 16 & 31,37 \\
2018 & 15 & 29,41 \\
\hline
\end{tabular}

2. Distribusi Penderita Karsinoma Kavum Nasal dan Sinus Paranasal Berdasarkan Jenis Kelamin, Usia dan Pekerjaan

Distribusi pasien berdasarkan jenis kelamin, usia dan pekerjaan dapat dilihat pada tabel 4.2. Penelitian ini ditemukan 31 laki-laki $(60,78 \%)$ dan 20 
perempuan $(39,21 \%)$ dengan perbandingan 1,5:1 dimana lebih banyak terdapat pada laki-laki daripada perempuan.

Tabel 2. Distribusi penderita karsinoma kavum nasal dan sinus paranasal berdasarkan jenis kelamin, usia, dan pekerjaan.

\begin{tabular}{|c|c|c|c|}
\hline & Karakteristik & $f(n=51)$ & $\%$ \\
\hline \multirow{3}{*}{$\begin{array}{l}\text { Jenis } \\
\text { kelamin }\end{array}$} & Laki-laki & 31 & 60,78 \\
\hline & & & \\
\hline & Perempuan & 20 & 39,21 \\
\hline \multirow[t]{9}{*}{ Usia } & $<20$ & 2 & 3,92 \\
\hline & 20 - 30 Tahun & 5 & 9,80 \\
\hline & 31 - 40 Tahun & 5 & 9,80 \\
\hline & 41 - 50 Tahun & 18 & 35,29 \\
\hline & $51-60$ Tahun & 16 & 31,37 \\
\hline & $>60$ Tahun & 5 & 9,80 \\
\hline & Min & 11 bulan & \\
\hline & Max & 71 tahun & \\
\hline & Mean & 46 tahun & \\
\hline \multirow[t]{8}{*}{ Pekerjaan } & Petani & 19 & 37,25 \\
\hline & Buruh & 0 & 0 \\
\hline & Pekerja kantor & 9 & 17,64 \\
\hline & Wiraswasta & 6 & 11,76 \\
\hline & Tidak bekerja & 1 & 1,96 \\
\hline & Ibu Rumah & 12 & 23,52 \\
\hline & Tangga & & \\
\hline & Lain-lain & 4 & 7,84 \\
\hline
\end{tabular}

Kelompok usia pada pasien karsinoma kavum nasal dan sinus paranasal dapat dilihat pada tabel.2 dengan kasus paling tinggi terjadi pada kelompok usia 41 - 50 tahun yaitu 18 orang (35,29\%). Penelitian ini didapatkan rerata usia pasien yaitu 46 tahun dengan usia paling muda 11 bulan dan usia paling tua 71 tahun.

Distribusi penderita karsinoma kavum nasal dan sinus paranasal berdasarkan pekerjaan dapat dilihat pada tabel 4.2 dengan kasus tertinggi terjadi pada petani yaitu 19 orang $(37,25 \%)$.

\section{Distribusi Kasus Karsinoma Kavum Nasal dan Sinus Paranasal Berdasarkan Keluhan Utama}

Distribusi keluhan utama karsinoma kavum nasal dan sinus paranasal terbanyak ditemukan dapat dilihat pada table 4.3. Penelitian ini ditemukan keluhan utama yang paling banyak dilaporkan yaitu hidung tersumbat yaitu 23 pasien (45,09\%) dan keluar darah dari hidung yaitu 10 pasien (19,60\%). Keluhan pada neurologi paling banyak pada nyeri kepala sebanyak 2 pasien (3,92\%). Keluhan pada wajah berupa benjolan di pipi sebanyak 4 pasien $(7,84 \%)$.

Tabel 3. Distribusi penderita karsinoma kavum nasal dan sinus paranasal berdasarkan keluhan utama

\begin{tabular}{lcc}
\hline Keluhan Utama & $\boldsymbol{f ( \mathbf { n } = \mathbf { 5 1 } )}$ & $\%$ \\
\hline Hidung: & 23 & 45,09 \\
Hidung tersumbat & 7 & 13,72 \\
Benjolan hidung & 10 & 19,60 \\
Keluar darah dari hidung & 2 & 3,92 \\
Sekret hidung bercampur darah & 2 & 3,92 \\
Nyeri hidung & 1 & 1,96 \\
\hline Neurologi: & 2 & 3,92 \\
Nyeri wajah & & \\
Nyeri kepala & 4 & 7,84 \\
\hline Wajah: & & \\
Benjolan di pipi &
\end{tabular}

\section{Distribusi Kasus Karsinoma Kavum Nasal dan Sinus Paranasal Berdasarkan Gejala Klinis}

Distribusi gejala klinis karsinoma kavum nasal dan sinus paranasal terbanyak ditemukan pada pasien dapat dilihat pada tabel 4.4. Pada penelitian ini, gejala klinis yang paling banyak dilaporkan yaitu hidung tersumbat yaitu 44 orang $(86,27 \%)$, keluar darah dari hidung yaitu 27 orang $(52,94 \%)$, dan nyeri kepala yaitu 22 orang $(43,13 \%)$. 
Tabel 4. Distribusi penderita karsinoma kavum nasal dan sinus paranasal berdasarkan gejala klinis

\begin{tabular}{|c|c|c|}
\hline Gejala Klinis & Ada $(\%)$ & Tidak Ada (\%) \\
\hline \multicolumn{3}{|l|}{ Hidung: } \\
\hline Hidung tersumbat & $44(86,27)$ & $7(13,72)$ \\
\hline Terdapat sekret hidung & $10(19,60)$ & $41(80,40)$ \\
\hline Benjolan hidung & $21(41,17)$ & $30(58,83)$ \\
\hline Hidung berbau & $3(5,88)$ & $48(94,12)$ \\
\hline Keluar darah hidung & $27(52,94)$ & $24(47,06)$ \\
\hline Sekret hidung bercampur darah & $6(11,76)$ & $45(88,24)$ \\
\hline Hidung berubah bentuk & $3(5,88)$ & $48(94,12)$ \\
\hline Penurunan kemampuan penghidu & $12(23,52)$ & $39(76,48)$ \\
\hline Nyeri hidung & $7(13,72)$ & $44(86,27)$ \\
\hline Susah bernafas & $4(7,84)$ & $47(92,16)$ \\
\hline \multicolumn{3}{|l|}{ Mata: } \\
\hline Penglihatan ganda & $6(11,76)$ & $45(88,24)$ \\
\hline Nyeri mata & $4(7,84)$ & $47(92,16)$ \\
\hline Keluar air mata berlebihan & $6(11,76)$ & $45(88,24)$ \\
\hline Pembengkakan mata & $3(5,88)$ & $48(94,12)$ \\
\hline Penonjolan bola mata & $10(19,60)$ & $41(80,40)$ \\
\hline Mata kabur & $11(21,56)$ & $40(78,44)$ \\
\hline \multicolumn{3}{|l|}{ Wajah: } \\
\hline Perubahan bentuk wajah & $1(1,96)$ & $50(98,04)$ \\
\hline Nyeri wajah & $4(7,84)$ & $47(92,16)$ \\
\hline Mati rasa wajah & $5(9,80)$ & $46(90,20)$ \\
\hline Benjolan wajah & $16(31,37)$ & $35(68,63)$ \\
\hline Pipi terasa penuh & $3(5,88)$ & $48(94,12)$ \\
\hline \multicolumn{3}{|l|}{ Neurologi: } \\
\hline Nyeri kepala & $22(43,13)$ & $29(56,87)$ \\
\hline \multicolumn{3}{|l|}{ Rongga Mulut: } \\
\hline Nyeri gigi & $2(3,92)$ & $49(96,08)$ \\
\hline Penonjolan di rongga mulut & $6(11,76)$ & $45(88,24)$ \\
\hline Suara sengau & $4(7,84)$ & $47(92,16)$ \\
\hline Gigi goyang & $1(1,96)$ & $50(98,04)$ \\
\hline Tukak rongga mulut & $1(1,96)$ & $50(98,04)$ \\
\hline Nyeri telan & $4(7,84)$ & $47(92,16)$ \\
\hline \multicolumn{3}{|l|}{ Telinga: } \\
\hline Penurunan pendengaran & $4(7,84)$ & $47(92,16)$ \\
\hline Telinga berdengung & $4(7,84)$ & $47(92,16)$ \\
\hline Telinga terasa penuh & $12(23,52)$ & $39(76,48)$ \\
\hline Telinga tidak mendengar & $1(1,96)$ & $50(98,04)$ \\
\hline Nyeri telinga & $1(1,96)$ & $50(98,04)$ \\
\hline \multicolumn{3}{|l|}{ Leher: } \\
\hline Benjolan leher & $12(23,52)$ & $39(76,48)$ \\
\hline Nyeri leher & $1(1,96)$ & $50(98,04)$ \\
\hline Tukak leher & $1(1,96)$ & $50(98,04)$ \\
\hline \multicolumn{3}{|l|}{ Lainnya: } \\
\hline Penurunan berat badan & $4(7,84)$ & $47(92,16)$ \\
\hline
\end{tabular}

\section{Distribusi Penderita Karsinoma Kavum Nasal} dan Sinus Paranasal Berdasarkan Lokasi Tumor

Lokasi karsinoma kavum nasal dan sinus paranasal dapat dilihat pada tabel 4.5, dimana paling banyak berlokasi pada kavum nasal sebanyak 30 kasus $(62,74 \%)$ diikuti oleh sinus maksila sebanyak 14 kasus $(27,45 \%)$, sinus ethmoid sebanyak 5 kasus $(9,80 \%)$, dan sinus sphenoid sebanyak 2 kasus (3,92\%). Pada penelitian ini tidak ditemukan karsinoma yang berlokasi di sinus frontal.
Tabel 5. Distribusi penderita karsinoma kavum nasal dan sinus paranasal berdasarkan lokasi tumor

\begin{tabular}{lcc}
\hline Lokasi Tumor & $\boldsymbol{f ( \mathbf { n } = \mathbf { 5 1 } )}$ & $\%$ \\
\hline Kavum nasal & 30 & 62,74 \\
Sinus ethmoid & 5 & 9,80 \\
Sinus sphenoid & 2 & 3,92 \\
Sinus frontal & 0 & 0 \\
Sinus maksila & 14 & 27,45 \\
\hline
\end{tabular}

\section{Distribusi Penderita Karsinoma Kavum Nasal dan Sinus Paranasal Berdasarkan Stadium Tumor}

Distribusi penderita karsinoma kavum nasal dan sinus paranasal berdasarkan stadium tumor dapat dilihat pada tabel 4.6 dimana umumnya pasien datang pada stadium IV. Pasien yang datang paling banyak pada stadium IVB yaitu 22 kasus $(43,13 \%)$ diikuti oleh stadium IVA yaitu 18 kasus (35,29\%), kemudian IVC yaitu 5 kasus $(9,80 \%)$, pada stadium III terdapat 4 kasus $(7,84 \%)$, pada stadium II terdapat 1 kasus (1,96\%) sedangkan pada stadium 0 dan I tidak ditemukan pasien yang datang berobat.

Tabel 6. Distribusi penderita karsinoma kavum nasal dan sinus paranasal berdasarkan stadium klinis

\begin{tabular}{lcc}
\hline Stadium Tumor & $\boldsymbol{f}(\mathbf{n}=\mathbf{5 1})$ & $\%$ \\
\hline 0 & 0 & 0 \\
I & 0 & 0 \\
II & 1 & 1,96 \\
III & 4 & 7,84 \\
IVA & 18 & 35,29 \\
IVB & 22 & 43,13 \\
IVC & 5 & 9,80 \\
\hline
\end{tabular}

7. Distribusi Penderita Karsinoma Kavum Nasal dan Sinus Paranasal Berdasarkan Tipe
Histopatologi

Pada penelitian hasil konfirmasi histopatologi pada karsinoma kavum nasal dan sinus paranasal dapat dilihat pada tabel 4.7, dimana tipe histopatologi terbanyak yaitu squamous cell carcinoma yaitu 30 kasus $(58,82 \%)$, diikuti oleh sinonasal undifferentiated carcinoma yaitu 8 kasus $(15,68 \%)$, dan salivary glandtype carcinoma yaitu 6 kasus $(11,76 \%)$. 
Tabel 7. Distribusi penderita karsinoma kavum nasal dan sinus paranasal berdasarkan tipe histopatologi

\begin{tabular}{lcc}
\hline Tipe Histopatologi & $\boldsymbol{f}(\mathbf{n}=\mathbf{5 1})$ & $\%$ \\
\hline Squamous cell carcinoma & 30 & 58,82 \\
Verrucous carcinoma & 2 & 3,92 \\
Lymphoepithelial carcinoma & 0 & 0 \\
Sinonasal undifferentiated & 8 & 15,68 \\
carcinoma & & \\
Adenocarcinoma & 2 & 3,92 \\
Salivary gland-type carcinoma & 6 & 11,76 \\
Neuroendocrine tumours & 3 & 5,88 \\
\hline
\end{tabular}

\section{PEMBAHASAN}

Berdasarkan penelitian mengenai gambaran klinis dan patologis karsinoma kavum nasal dan sinus paranasal di Bagian THT-KL RSUP Dr. M. Djamil Padang tahun 2016-2018 terdapat 57 kasus karsinoma kavum nasal dan sinus paranasal. Dari keseluruhan data didapatkan 51 kasus karsinoma kavum nasal dan sinus paranasal yang memenuhi kriteria inklusi dan terdapat 6 kasus yang masuk kedalam kriteria eksklusi karena pasien tidak melanjutkan pengobatan sehingga menyebabkan tidak lengkapnya data yang dibutuhkan. Hasil penelitian secara keseluruhan dilampirkan di bagian halaman belakang.

Pada penelitian ini didapatkan data bahwa kejadian karsinoma kavum nasal dan sinus paranasal mengalami penurunan setiap tahun yaitu pada tahun 2016 (39,21\%), tahun 2017 (31,37\%), dan 2018 $(29,41 \%)$. Hal ini dapat disebabkan oleh berkurangnya jumlah pasien karsinoma kavum nasal dan sinus paranasal yang datang berobat ke bagian THT-KL pada tahun 2016 hingga 2018.

Pada penelitian ini, dilaporkan terdapat 31 laki-laki $(60,78 \%)$ dan 20 perempuan $(39,21 \%)$ dengan perbandingan 1,5:1 dimana lebih banyak terdapat pada laki-laki daripada perempuan. Menurut penelitian Haque et al, terdapat 29 pasien laki-laki $(72,5 \%)$ dan 11 pasien perempuan $(27,5 \%)$ dimana perbandingan laki-laki dengan perempuan yaitu 2,6:1. ${ }^{10}$

Pada penilitan Turner dan Reh (2012), kejadian karsinoma kavum nasal dan sinus paranasal berdasarkan jenis kelamin memiliki perbandingan 1,8:1 pada laki-laki dan perempuan. ${ }^{11}$. Dilaporkan adanya penurunan kejadian pada laki-laki sedangkan pada perempuan tetap stabil. $^{12}$
Secara umum, laki-laki yang memiliki pekerjaan yang terpapar dengan kayu berisiko lebih tinggi pada keganasan ini. Penelitian yang dilakukan oleh Jayaprakash et al menemukan bahwa laki-laki yang memiliki faktor risiko lebih dari satu seperti terpapar oleh debu kayu disertai paparan zat kimia lainnya berisiko lebih tinggi mengalami keganasan. ${ }^{17}$

Kasus terbanyak ditemukan pada rentang usia 41 - 50 tahun yaitu 18 orang $(35,29 \%)$ dan usia 51 - 60 tahun sebanyak 16 orang $(31,37 \%)$. Pada penelitian ini ditemukan $76,46 \%$ pasien pada usia diatas 40 tahun. Hasil yang sama ditemukan pada penelitian Fadly dan Asnir di Medan terdapat 75,89\% pasien pada usia diatas 40 tahun. $^{5}$ Berdasarkan penelitian Shavilla et al, Bandung sebanyak $79 \%$ pasien datang pada usia diatas $45-85$ tahun. $^{7}$

Berdasarkan penelitian Shirazi et al, ditemukan 37,30\% pasien pada usia kurang dari 40 tahun. ${ }^{18}$ Penelitian Fadly dan Asnir menemukan terdapat pasien dibawah usia 40 tahun sebanyak $24,1 \%$. Pada penelitian ini, ditemukan $23,54 \%$ pasien usia kurang dari 40 tahun. $^{5}$

Faktor risiko seperti paparan terhadap debu kayu dan pekerjaan yang behubungan dengan peningkatan risiko terhadap karsinoma kavum nasal dan sinus paranasal umumnya timbul pada 40 tahun setelah paparan pertama kali. ${ }^{8}$ Akumulasi bertahuntahun dari konsumsi tembakau dan alkohol pada usia paruh baya berperan dalam perkembangan dari keganasan tersebut. ${ }^{6}$

Kejadian karsinoma kavum nasal dan sinus paranasal pada pasien dibawah 40 tahun dapat disebabkan oleh konsumsi tembakau dan alkohol, diet yang tidak sehat, Human Papilloma Virus, serta paparan zat kimia yang bersifat karsinogenik. ${ }^{19}$ Paparan asap pada pengendara kendaraan bermotor di usia dewasa muda meningkatkan risiko keganasan ini, karena keganasan ini merupakan penyakit yang berhubungan dengan lingkungan. ${ }^{7}$ Faktor risiko terjadinya keganasan pada bayi dapat disebabkan oleh usia ibu saat mengandung, obat yang dikonsumsi oleh ibu saat mengandung, penggunaan kafein dan alkohol, serta udara lingkungan yang buruk.

Pada penelitian ini, kasus karsinoma kavum nasal dan sinus paranasal banyak ditemukan pada petani yaitu 17 orang $(38,63 \%)$. Hasil penelitian ini 
sejalan dengan penelitian Haque et al, terdapat 16 orang $(40 \%)$ yang bekerja sebagai petani. ${ }^{10}$

Pekerjaan yang menggunakan pestisida seperti petani dan pekerja kebun meningkatkan risiko karsinoma kavum nasal dan sinus paranasal sebesar $50 \%$. Beberapa kandungan pestisida yaitu pentachlorophenol, lindane, transfluthrin, cyfluthrin dan natural pyrethrum memberikan efek genotoksik yang kuat apabila terpapar pada sel mukosa konka nasalis inferior hingga media. ${ }^{20}$

Berdasarkan penelitian Bakari et al, ditemukan sebanyak 13 pasien $(17,4 \%)$ yang bekerja sebagai ibu rumah tangga. ${ }^{21}$ Riwayat kebiasaan menggunakan kayu bakar untuk memasak dapat meningkatkan risiko karsinoma kavum nasal dan sinus paranasal. Paparan debu kayu dan asap hasil pembakaran tersebut merupakan zat karsinogenik yang apabila terakumulasi dalam jangka waktu yang lama akan memicu keganasan. ${ }^{22}$

Pada penelitian ini, keluhan utama yang paling banyak dilaporkan adalah keluhan pada hidung berupa hidung tersumbat yaitu 23 pasien (45,09\%) dan keluar darah dari hidung yaitu 10 pasien (19,60\%). Walaupun massa berasal dari neuroepitel olfaktorius, penurunan kemampuan penghidu jarang dilaporkan oleh pasien. $^{23}$

Berdasarkan penelitian Mahalingappa dan Khalil, terdapat hidung tersumbat pada satu sisi sebanyak 15 pasien (50\%) diikuti adanya benjolan dan keluar darah dari hidung sebanyak 5 pasien (17\%). ${ }^{14}$ Pada penelitian Juli et al, keluhan utama yang dilaporkan yaitu hidung tersumbat di satu sisi dan sekret hidung bercampur darah sebesar $79,9 \%{ }^{7}$ Paparan zat karsinogenik pada hidung menyebabkan terjadinya airway remodeling, pada proses ini, dapat terjadi hiperplasia jaringan stromal berupa penebalan subepitel sehingga menimbulkan sumbatan pada hidung. Penebalan jaringan ini diikuti dengan bertambahnya anyaman pembuluh darah sehingga apabila terdapat faktor pencetus dapat menimbulkan perdarahan pada hidung. ${ }^{24}$

Pada penelitian ini, gejala klinis yang paling banyak dilaporkan yaitu hidung tersumbat yaitu 44 orang $(86,27 \%)$, keluar darah dari hidung yaitu 27 orang $(52,94 \%)$, dan nyeri kepala yaitu 22 orang $(43,13 \%)$. Hasil yang sama ditemukan pada penelitian yang dilakukan Chalastras et al, gejala klinis terbanyak adalah hidung tersumbat yaitu 12 pasien $(31,57)$, keluar darah dari hidung yaitu 7 pasien $(18,42 \%)$ dan nyeri kepala yang tidak sembuh dengan obat analgesia sebanyak 6 pasien (15,78\%). ${ }^{25}$

Sumbatan hidung pada karsinoma sinus paranasal dan kavum nasi dapat disebabkan oleh adanya massa pada hidung atau perubahan inverted papilloma yang berkembang menjadi keganasan. ${ }^{27}$ Sakit kepala menunjukkan adanya perluasan keganasan ke intracranial dan adanya invasi ke dasar tengkorak. $^{26}$

Berdasarkan lokasi tumor, penelitian ini menunjukkan karsinoma kavum nasal dan sinus paranasal paling banyak ditemukan pada kavum nasal sebanyak 30 kasus (62,74\%) diikuti oleh sinus maksila sebanyak 14 kasus $(27,45 \%)$, sinus ethmoid sebanyak 5 kasus $(9,80 \%)$, dan sinus sphenoid sebanyak 2 kasus (3,92\%). Sedangkan apabila hanya dikelompokkan berdasarkan sinus paranasal, sinus maksilla merupakan lokasi paling banyak ditemukan yaitu $61,11 \%$ dalam keganasan ini. Pada penelitian ini tidak ditemukan karsinoma yang berlokasi di sinus frontal.

Hasil penelitian ini sesuai dengan penelitian Turner dan Reh, sebagian besar lesi keganasan ini paling banyak berlokasi di kavum nasal (43,9\%), sebagian lainnya di sinus maksilla (35,9\%), dan di sinus ethmoid (9,5\%). ${ }^{11}$ Keganasan pada sinus frontalis dan sinus sphenoid jarang dilaporkan, hanya terdapat $1,1 \%$ pada sinus frontalis dan $3,3 \%$ pada sinus sphenoid. ${ }^{12}$ Penelitian Mahalinggappa dan Khalil, juga menunjukkan bahwa lokasi keganasan ini paling banyak ditemukan pada kavum nasal (57\%), lalu sinus maksila (27\%), dan sinus ethmoid (10\%) dari seluruh pasien. Keganasan pada sinus frontalis dan sinus sphenoid jarang dilaporkan. ${ }^{14}$

Pada penelitian ini ditemukan bahwa pasien umumnya datang pada stadium lanjut yaitu III dan IV. Pasien yang datang paling banyak pada stadium IVB yaitu 22 kasus $(43,13 \%)$ diikuti oleh stadium IVA yaitu 18 kasus (35,29\%), kemudian IVC yaitu 5 kasus $(9,80 \%)$, pada stadium III terdapat 4 kasus $(7,84 \%)$, pada stadium II terdapat 1 kasus (1,96\%) sedangkan pada stadium 0 dan I tidak ditemukan pasien yang datang berobat. Penelitian ini sejalan dengan 
penelitian Christopherson et al, ditemukan pasien stadium IVB sebanyak 15 orang (65\%) dan diikuti stadium IVA yaitu 7 orang (30\%). ${ }^{27}$

Berdasarkan penelitian Rahman, umumnya pasien datang pada stadium IV (60\%), diikuti stadium III (26,6\%), stadium II (13,3\%) dan tidak terdapat pasien yang datang pada stadium I. $^{6}$ Penelitian Mahalingappa dan Khalil, menunjukkan bahwa pasien umumnya datang pada stadium lanjut yaitu IV (50\%) dan stadium III (20\%), diikuti stadium II (17\%) dan stadium I (17\%). ${ }^{14}$

Anatomi sinus paranasal merupakan rongga tersembunyi dalam tulang sehingga sulit dideteksi dengan pemeriksaan fisik biasa yang menyebabkan gejala tumor stadium dini bersifat asimptomatik. ${ }^{8}$ Gejala tidak khas yang kurang diperhatikan pada keganasan ini menjadi salah satu alasan terjadinya kesalahan diagnosis. Umumnya pasien datang apabila telah mengalami gejala berat akibat perluasan tumor. ${ }^{5}$

Pada penelitian ini, didapatkan hasil konfirmasi histopatologi pada karsinoma kavum nasal dan sinus paranasal yang paling banyak ditemukan yaitu squamous cell carcinoma yaitu 30 kasus $(58,82 \%)$, diikuti oleh sinonasal undifferentiated carcinoma yaitu 8 kasus (15,68\%), dan salivary glandtype carcinoma yaitu 6 kasus $(11,76 \%)$. Penelitian ini sejalan dengan penelitian yang dilakukan Rahman dan Chandra, dilaporkan squamous cell carcinoma sebagai jenis histopatologi yang paling sering ditemukan yaitu $53,3 \%$, diikuti undifferentiated carcinoma (13,3\%) dan adenocarsinoma $(13,3 \%){ }^{6}$

Menurut penelitian Guleria et al, di India didapatkan jenis histopatologi yang paling sering ditemukan yaitu squamous cell carcinoma (40\%), diikuti adenoid cystic carcinoma (20\%), dan malignant melanoma $(15 \%) .^{28} \quad$ Berdasarkan penelitian Poursadegh et al di Iran, ditemukan 28 pasien squamous cell carcinoma (40,6\%), diikuti adenoid cystic carcinoma yaitu 8 orang (11,6\%), dan hodgkin lymphoma sebanyak 6 orang $(8,7 \%){ }^{29}$ Tipe histopatologis karsinoma kavum nasal dan sinus paranasal dapat berbeda di setiap negara, hal ini disebabkan oleh perbedaan pekerjaan, lingkungan dan faktor genetik. $^{14}$
Kavum nasal dan sinus paranasal dilapisi oleh pseudostratified epithelia, sel goblet dan glandula sekretorius submukosa akan memproduksi mukus untuk menangkap benda asing. Perubahan sel epitel ini berpotensi mengalami metaplasia dimana dapat berkembang menjadi keganasan. ${ }^{5}$ Distribusi epitel mukosa yang melapisi saluran pernapasan atas menyebabkan tipe squamous cell carcinoma banyak ditemukan pada keganasan ini. ${ }^{30}$

\section{SIMPULAN}

Berdasarkan hasil penelitian terhadap pasien karsinoma kavum nasal dan sinus paranasal yang datang di Bagian THT-KL RSUP Dr. M. Djamil Padang tahun 2016-2018 didapatkan kesimpulan bahwa terdapat 57 kasus karsinoma kavum nasal dan sinus paranasal dan hanya 51 kasus yang memenuhi kriteria inklusi sebagai sampel penelitian, dengan pasien paling banyak dilaporkan pada tahun 2016. Sebagian besar pasien adalah laki-laki. Distribusi kelompok umur terbanyak adalah usia antara 41 - 50 tahun. Mayoritas pasien bekerja sebagai petani. Keluhan utama terbanyak yang membawa pasien datang berobat adalah hidung tersumbat. Gejala klinis yang paling banyak ditemukan yaitu hidung tersumbat. Lokasi tumor pada karsinoma kavum nasal dan sinus paranasal terbanyak ditemukan adalah kavum nasal. Pada umumnya penderita datang berobat pada stadium lanjut (III dan IV), sedangkan tidak ditemukan pasien yang datang pada stadium 0 dan I. Tipe histopatologis terbanyak yang ditemukan adalah squamous cell carcinoma.

\section{UCAPAN TERIMA KASIH}

Terima kasih kepada semua pihak yang telah membantu dalam pelaksanaan penelitian. Kepada Direktur Umum RSUP Dr. M Djamil Padang yang telah memberikan izin melaksanakan penelitian dan kepada staf bagian rekam medik yang telah membantu penulis dalam melaksanakan penelitian. 


\section{DAFTAR PUSTAKA}

1. Bossi P, Farina D, Gatta G, Lombardi D, Nicolai P, Orlandi E. Paranasal sinus cancer. Crit Rev Oncol Hematol.2016; 98: 45-61.

2. Sanghavi S, Khan MN, Patel NR, Yeldandi S, Baredes S, Eloy JA. Analysis of 4994 patients. Laryngoscope. 2014; 124(1): 76-83

3. American Cancer Society. Nasal cavity and Paranasal Sinuses Cancer. 2018 [Cited 2018 October 18]. Available from: URL: https://www.camcer.org/cancer/nasal-cavityandparanasal-sinus-cancer.html.

4. Ansa B, Goodman M, Ward K, Kono SA, Owonikoko TK, Higgins $\mathrm{K}$, et al. Paranasal sinus squamous cell carcinoma incidence and survival based on surveillance, epidemiology, and end result data 1973 to 2009. Cancer. 2013; 119(14): 2602-10.

5. Fadly F, Asnir RA. Profile of sinoasal malignant tumor patients in Adam malik General Hospita Medan-Indonesia. Bali Med J. 2018; 7(1): 137-40.

6. Rahman S. Clinico-Pathological Characteristic of sinonasal malignancies: a study from a Tertiary care hospital of Indonesia. ANZ journal of surgery. 2014; 84(Suppl. 1): 92-3.

7. Juli J, Shavilla E, Aroeman NA, Dewi YA, et al. Prevalensi kanker sinonasal di Poliklinik THT-KL RS Hasan Sadikin Bandung. Tun Med J Ked Kes. 2015; 3(1): 2-4.

8. Rahman S, Firdaus MA. Tumor sinus paranasal dengan perluasan intracranial dan metastasis ke paru. Jurnal Kesehatan Andalas. 2012;1(3):150-6.

9. Nayak M, Roul B, Agrawal K, Nayak S. Clinicopathological study lesions of sinonasal tract and distribution od sinonasaltract lessions in different age group and sex. Ann Path Lab Med. 2015; 3(4): 726-33.

10. Haque MM, Ali MI, Harun-Ar-Rashid, Islam MT, Rahman M, Chowdhury MA. Presentation of sinonasal carcinoma. Bangladesh J otorhinolaryngol. 2014;19(2).

11. Turner JH, Reh DD. Incidence and survival in patients with sinonasal Cancer: A Historical analysis of population based data. Head Neck. 2012; 34(6): 877-85.
12. Binazzi $A$, Ferrante $P$, Marinaccio A. Occupational exposure cancer: A system review and metaanalysis. BMC Cancer. 2015; 15(1): 9-15.

13. Stimpson $P$, Dealwis N, Merriel SWD, Sigston E. Accuracy od PET-CT for preoperative staging of nodal metastases in head and neck cancer patients. ANZ J Surg. 2014;84:90.

14. Mahalingappa YB, Khalil HS. Sinonasal malignancy: Presenatation anda outcomes. J Laryngol Otol. 2014; 129(7): 654-7.

15. Lund VJ, Clarke PM, Swift AC, McGarry GW, Kerawala C Carnell D. Nose and paranasal sinus tumors: United Kingdom National Multidiscipilnary Guidelines. J Laryngol Otol. 2016; 130(2): 111-8.

16. Homma A, Sakashita T, Yoshida D, Onimaru R. Tscuchiya K, Suzuki $F$, et al. Superselective intraarterial cisplatin infusion and concomitant radiotherapy for maxillary sinus cancer: $\mathrm{Br} J$ Cancer. 2013; 109 (12):2980-6

17. Jayapraksh V, Natarajan KK, Moysich KB, Rigual NR, Ramnath N, Natarajan N, Reid ME. Wood dust exposure and the risk of upper aero-dugestive and respiratory cancer in meals. Occup environ med j. 2009;1(65):674-54.

18. Shirazi N, Bist SS, Selvi TN, Harsh M. Spectrum of sinonasal tumors: A 10-years experience at a tertiary care Hospital in North Indua. Oman Mej J. 2015; 30(6): 435-40.

19. Jegoux F, et al. Paranasal sinus cancer. Eur Ann Otorhinolaringol, head neck dis. 2013; 130(6): 327 35

20. Greiser EM, Greiser H, Ahrens w, Hagen R, Lazszig $\mathrm{R}$, Marier $\mathrm{H}$. Risk factors for nasal malignancies in German meb: the south-german Nasal cancer study. BMC Cancer. 2012; 47: 1-12.

21. Bakari A, Afolabi OA, Adoga AA, Kodiya AM, Ahmad BM. Clinico-phatological profile of sinonasal masses: an experience in national ear care center Kaduna, Nigeria. BMC Res Notes. 2010;3:186.

22. Slack R, Young C, Rushion L. Occupational cancer in Britain. Br J cancer. 2012; 107(1):92-103.

23. Thompson LDR. Olfactory Neuroblastoma. Indian J Otolaryngol. 2009; 30(2): 97-8.

24. Beule AG. Physiology and pathophysiology of respiratory mucosaa od the nose and the 
paranasal sinuses. GMS Curr Top

otorhinolaryngol, head neck surg. 2010; 9: 7.

25. Chalastras T, Elefteridou A, Giotakis J, Soulandikas K, Korres S, Ferekidis E, et al. Nonhodgkin lymphoma of nasal cavoty and paranasal sinus. A clinicophatological and immunohistochemical. Acta Otorhinolaryngol Ital. 2007; 27(1): 6-9.

26. Ramachamoarambathu AK, Vengal M, Mufeed A, Siyo N, Ahmed A. Carsinoma of maxillary sinus masquerading as odontogenic infection. J Clin Diagnostic Res. 2016; 10(9): 11-13.

27. Christopherson K, Werning JW, Malyapa RS, Morris CG. Mendenhall WM. Radiotherapy for sinonasal undifferentiated carcinoma. Am J otolaryngol. $2014 ; 35(2)$ : 141-6.

28. Guleria TC, Mohindroo S, Mohindo NK, Azad RK, Kumar A. Histophatological profle of nasal cavity, paranasala sinuses, and nasopharyngeal masses in hill state of Himachal Pradesh, India. Clin Rhinol 2017; 10(2):93-8.

29. Poursadegh $M$, Poursadegh F, Esmaeili M, Bakhsahee M. Epdemiological survey of sinonasal malignancy in north-east Iran. Iran $J$ Otorhinolaryngol. 2015; 27(80):225-9.

30. Shanmugaratnam K. Histological typing of tumours of the upper respiratory tract and ear. Springer Science \& Business Media; 2012;2:32-3 